\title{
V. Valli, The American Economy from Roosevelt to Trump
}

\section{7 pp., Palgrave Macmillan, Basingstoke (Hampshire), 2018, $29 €$}

\author{
Andreas Freytag ${ }^{1,2,3}$
}

Published online: 28 August 2020

(C) The Author(s) 2020

This book by Vittorio Valli presents the economic history of the United States since the early 20th Century until the second year of the Trump Administration. Although the author does not separate the book into individual parts, but into twelve chapters, the reader still gets the impression of three only loosely connected parts.

The first part of the book is a chronological narrative of the rise of the American economy in five chapters. It starts with a chapter on the ascent of the United States, where Valli concentrates on the role of the frontier creating strong economic incentives for American citizens. An important feature of this ascent is the production concept labelled as Fordism, which is well explained in second chapter. The third chapter is dedicated to the Great Depression and the political reaction (The New Deal), which definitely finds the sympathy of the author. This is a very readable chapter. Chapter 4 deals with the post WWII-economy. The US was the strongest economy after the war and returned to the Fordist model, which became obsolete in the early 1970s. Other countries made use of this model too, and were able to catch up significantly, in particular Japan and Germany. Chapter 5 deals with the role of technological progress and the accumulation of capital, human capital and knowledge in the US economy. It starts with an important reflection about the role of institutions, especially non-extractive institutions. This part of the book offers a very concise and well-structured narrative about the economics and politics of the rise of the US economy. It is the strongest part. Valli does not judge, he offers facts.

This changes in the second part of the book where the author takes a much more normative perspective. In three chapters (6-8), he first discusses the global power of the US, second presents weaknesses, before he speculates about a grand strategy of the US government. Chapter 6 is a rather superficial and confuse attempt to explain US power (without defining it well) with the help of an arbitrary selection of

Andreas Freytag

a.freytag@wiwi.uni-jena.de

1 Friedrich-Schiller-Universität Jena, Jena, Germany

2 University of Stellenbosch, Stellenbosch, South Africa

3 CESifo Research Network, Munich, Germany 
indicators, which the author aggregates into a Turin Economic Power Index. It is not quite clear, which function this chapter has. This question is particularly relevant since Chapter 7 is discussing all sorts of weaknesses in the US economic power. These weaknesses are the dependence on natural resources (why?), the environmental problems (which are rather institutional weaknesses), the ups and downs of the US economy (which happen everywhere), a rising deficit in the current account, a weaker US-Dollar and a few institutional problems such as rising inequality, organized crime and the decline of democracy. This is an arbitrary list, which should have been categorized, for instance in internal vs. external problems, technical vs. institutional problems etc. In particular, the author displays a shocking lack of theoretical understanding for instance of the balance of payments. In a very traditional and mercantilist manner, he sees a current account deficit as a general problem without reference to an intertemporal calculus and the attractive investment conditions in the US where also the population is growing, which suggest that a surplus in the capital account (with an according deficit in the current account) is beneficial for the US economy - at least as long as state finances are sustainable. The author completely ignores such line of argument. In chapter 8, the author develops a narrative of a grand strategy to make the US an Empire since World War II. This rather reads like a conspiracy theory.

The third part consists of an account of the last decades with an overview about the Great Recession (as correctly differentiated from the Great Depression), the Obama years and the first two years of the Trump administration. These three chapters are much more readable again, because facts dominate and obscure judgement is avoided.

In sum this book is a mixed blessing. It could be a great read, given the enormous wealth of facts and the author's broad knowledge of American contemporary history. However, the author is satisfied with very simple explanations, takes it for granted that liberal economic policies are the main contributors to crises and neglects important theoretical strands.

Funding Open Access funding provided by Projekt DEAL.

Open Access This article is licensed under a Creative Commons Attribution 4.0 International License, which permits use, sharing, adaptation, distribution and reproduction in any medium or format, as long as you give appropriate credit to the original author(s) and the source, provide a link to the Creative Commons licence, and indicate if changes were made. The images or other third party material in this article are included in the article's Creative Commons licence, unless indicated otherwise in a credit line to the material. If material is not included in the article's Creative Commons licence and your intended use is not permitted by statutory regulation or exceeds the permitted use, you will need to obtain permission directly from the copyright holder. To view a copy of this licence, visit http:// creativecommons.org/licenses/by/4.0/.

Publisher's note Springer Nature remains neutral with regard to jurisdictional claims in published maps and institutional affiliations. 